\title{
Towards a deeper understanding of fatty acid bioaccessibility and its dependence on culinary treatment and lipid class: a case study of gilthead seabream (Sparus aurata)
}

\author{
Sara Costa $^{1}$, Cláudia Afonso ${ }^{1,2 *}$, Carlos Cardoso $^{1,2 *}$, Rui Oliveira ${ }^{1}$, Francisca Alves ${ }^{1}$, Maria L. Nunes ${ }^{2}$ and \\ Narcisa M. Bandarra ${ }^{1,2}$ \\ ${ }^{1}$ Division of Aquaculture and Upgrading (DivAV), Portuguese Institute for the Sea and Atmosphere (IPMA, IP), Rua Alfredo \\ Magalhães Ramalho, 6, 1495-006 Lisbon, Portugal \\ ${ }^{2}$ CIIMAR, Interdisciplinary Centre of Marine and Environmental Research, University of Porto, Rua dos Bragas 289, 4050-123 \\ Porto, Portugal
}

(Submitted 31 May 2016 - Final revision received 3 October 2016 - Accepted 4 October 2016 - First published online 8 November 2016)

\section{Abstract}

The bioaccessibility of total lipids and fatty acids (FA) in raw and grilled gilthead seabream (Sparus aurata) was determined using an in vitro digestion model. The particular impact of grilling on the FA profile of seabream was also studied. In addition, the influence of lipid class on the bioaccessibility of each FA was analysed. Grilling did not change the relative FA profile, and only the absolute values were altered. However, the relative FA profile varied across lipid classes, being more dissimilar between TAG and phospholipids. Long-chain SFA and PUFA seemed to be less bioaccessible. Moreover, grilling reduced bioaccessibility of protein, fat and many FA, with the highest reductions found in PUFA such as the DHA. Strong evidence supporting a predominantly regioselective action of lipase during in vitro digestion was found, and the impact of this phenomenon on FA bioaccessibility was assessed.

\section{Key words: Bioaccessibility: Gilthead seabream: Culinary treatments: Lipid classes: Fatty acid profile}

Health and nutrition are intimately linked. This raises the issue of quantifying and balancing the constituents associated with a given food. Such an analysis requires knowledge of those constituents' concentrations that are effectively absorbed by the human body ${ }^{(1)}$. In order to achieve this purpose, one must take into account that foods are typically subjected to further culinary treatment before ingestion and that the level of a nutrient in a food that is eaten may be quite different from the bioaccessible level - that is, the component concentration that is released from the food matrix into the intestinal lumen after digestion $^{(1)}$.

According to the literature ${ }^{(2,3)}$, the culinary procedures used to prepare fish are associated with important physical and chemical changes - namely, moisture variation, alterations in the ability to retain moisture, discolouration, building up of particular aromas and textural transformations. These latter changes have been ascribed to protein denaturation ${ }^{(4)}$. Moreover, the influence of cooking upon bioaccessibility and the characteristics of the bioaccessible part are not well known. It should be remarked that, for any particular food nutrient or contaminant, bioaccessibility is a gauge of its maximal bioavailability - the portion of that nutrient/contaminant that is able to achieve systemic circulation ${ }^{(1)}$. In addition, depending on numerous factors such as type and processing of food, the studied food constituent may be more or less bioavailable ${ }^{(5-7)}$.

Recent experimental studies have been carried out with the aim of finding a suitable in vitro digestion model that is able to simulate in a realistic way the human digestive system ${ }^{(1)}$. Such a challenge is compounded with extra technical difficulties when the targeted food constituent is also present in the substances used for the simulation of digestion, as in the case of lipids, which are found in the bile ${ }^{(5)}$. Indeed, there are only a few studies on lipid bioaccessibility ${ }^{(1,8)}$. Besides, lipid class distribution of fatty acids (FA) may influence the bioaccessibility of particular FA, thereby adding another layer of complexity to the issue. For instance, it has been observed in in vivo studies with humans that FA bound to TAG are more bioavailable than FA bound to ethyl esters EE) ${ }^{(9,10)}$. These EE can be found in fish oil supplements, but not in the large majority of foods.

On the other hand, fish contain significant amounts of $n-3$ PUFA - namely, EPA and DHA - which are associated with decreased morbidity and mortality from CVD and other diseases as well as with fetal development ${ }^{(11)}$. This justifies a greater attention to the issue of FA bioaccessibility in seafood. In

Abbreviations: FA, fatty acids; MAG, monoacylglycerol; PL, phospholipids; PPL, porcine pancreatic lipase.

* Corresponding author: C. Afonso, email cafonso@ipma.pt; C. Cardoso, carlos_1_cardoso@hotmail.com 
particular, in the general context of increasing worldwide demand for fish products and the decline in wild marine resources, farmed fish has gained much importance ${ }^{(12)}$, with gilthead seabream (Sparus aurata) being one of the most valued and consumed seafood ${ }^{(12)}$.

Therefore, seabream was selected for this case study in order to achieve a deeper understanding of FA bioaccessibility and its dependence on the changes occurring during a more drastic culinary treatment (grilling) and on the particular lipid class distribution of each FA.

\section{Methods}

\section{Fish samples}

The sampling and the cooking methods used are described in detail by Costa et $a l .{ }^{(13)}$. In brief, gilthead seabream (S. aurata) were supplied by a Portuguese fish farm (average weight: 430 (SD 22) g; average length: $30(\mathrm{SD} 1) \mathrm{cm}$ ). Fish were gutted, beheaded, washed and sliced in half. One fillet was used for the culinary treatment and the other was used as the corresponding raw sample.

In each traditional cooking treatment, nine individuals were included. The grilling process was performed as described by Costa et al. ${ }^{(13)}$. After cooking, the skin and bones were removed, and the collected edible part was homogenised. This material was separated into two sub-samples: one was frozen and stored at $-80^{\circ} \mathrm{C}$, and the other was frozen at $-20^{\circ} \mathrm{C}$, freezedried and then stored at $-80^{\circ} \mathrm{C}$ until further analysis.

\section{Bioaccessibility}

Raw and grilled seabream samples were used to determine the bioaccessibility of fat and its components. Grilling is an ideal process for studying the influence of culinary treatments, as it belongs to the group of harsh cooking methods (from the point of view of its impact on the concentrations of fish constituents) ${ }^{(14)}$

For this purpose, seabream samples were subjected to a previously perfected in vitro digestive model that simulates the regular physiology of the human digestive system with typical meals and quantities of food ${ }^{(5)}$. There were no changes to the described methodology.

The bioaccessibility (\%) of lipid, FA and protein was calculated in the same way ${ }^{(5)}$, with the concentration of the nutrient found in the enzyme solution subtracted from the final result.

\section{Analyses}

Moisture, protein and lipid contents. Moisture content was determined according to Association of Analytical Communities methods ${ }^{(15)}$ by drying samples at $105^{\circ} \mathrm{C}$. The protein level was quantified using a combustion method of analysis with the FP-528 DSP LECO nitrogen analyzer (LECO) calibrated with EDTA according to the Dumas method ${ }^{(16)}$. Total fat was determined following the Smedes extraction method ${ }^{(17)}$ using propan-2-ol and cyclohexane as solvents.
Lipid extraction. Extraction of fat from raw and grilled seabream samples was carried out using the Smedes technique ${ }^{(17)}$. On the other hand, a different method was applied for lipid extraction from the bioaccessible portion, because fat is released from the food matrix into the bioaccessible phase as a consequence of several steps involved in the in vitro model. This procedure was identical to that previously described for salmon ${ }^{(8)}$.

Lipid class determination. The amount of different lipid classes was estimated by TLC following an optimised technique ${ }^{(18)}$. For elution, a mixture of hexane-diethyl ether-acetic acid (50:50:2, $\mathrm{v} / \mathrm{v} / \mathrm{v}$ ) and a $0.25-\mathrm{mm}$ silica gel $\mathrm{G}$ plate were combined. The position of each lipid class was confirmed through elution of a mixture of standards (Sigma Chemical Co.). The relative importance of the various lipid classes was assessed and quantified on the basis of image analysis with a GS-800 densitometer and version 4.5.2 of Quantity One 1-D Analysis software from Bio-Rad.

Separation of lipid classes and fatty acid profile. The different lipid classes were separated for FA analysis according to previously described procedures involving solid-phase extraction and preparative $\operatorname{TLC}^{(8)}$. Main fat classes, TAG, diacylglycerol (DAG), monoacylglycerol (MAG), NEFA and phospholipids (PL) were confirmed by sigma standards.

The FA profile was determined in seabream before and after digestion (bioaccessible portion) by acid-catalysed transesterification, as described by Bandarra et al. ${ }^{(19)}$. Results in mg/100 g were attained through the peak area ratio and the lipid adjustment coefficients proposed by Weihrauch et al. ${ }^{(20)}$.

\section{Statistics}

All data were analysed using STATISTICA 6 software (StatSoft Inc.). One-way ANOVA was used to determine significant differences $(P<0.05)$ between raw and grilled seabream, and a factorial ANOVA was applied to determine significant differences $(P<0.05)$ among lipid classes and between FA (before and after digestion), followed by a multiple comparison test (Tukey's honest significant difference; HSD). When data could not satisfy normal distribution and homoscedasticity requirements, differences were analysed with non-parametric ANOVA (Kruskal-Wallis) followed by non-parametric multiple comparisons test (or Mann-Whitney) ${ }^{(21)}$.

\section{Results and discussion}

\section{Effect of culinary treatment}

Lipid fraction. The lipid content of seabream edible muscles was analysed in raw and grilled fish (Table 1). The lipid content was reduced because of oil drip losses during grilling. The main lipid classes in raw and grilled seabream before digestion are shown in Table 2 and were similar. Seabream has a large share of storage lipids, mainly found as TAG, as in other fish species ${ }^{(22)}$. Indeed, the TAG were always over $85 \%$ of the total fat content, whereas structural lipids, mainly PL, comprised $4-5 \%$ of the total fat content. The NEFA fraction was also in this range. 
Table 1. Protein and lipid contents $(\mathrm{g} / 100 \mathrm{~g})$ as well as the fatty acid profile $(\mathrm{mg} / 100 \mathrm{~g})$ of raw and grilled gilthead seabream

(Averages and standard deviations)

\begin{tabular}{|c|c|c|c|c|}
\hline & \multicolumn{2}{|c|}{ Raw fish } & \multicolumn{2}{|c|}{ Grilled fish } \\
\hline & Average & SD & Average & SD \\
\hline Protein & $22 \cdot 5^{\mathrm{a}}$ & 0.8 & $26 \cdot 4^{a}$ & 3.6 \\
\hline Lipid & $6 \cdot 2^{\mathrm{a}}$ & $1 \cdot 1$ & $5 \cdot 1^{\mathrm{b}}$ & 0.9 \\
\hline $14: 0$ & $216 \cdot 9^{a}$ & $12 \cdot 1$ & $174.9^{b}$ & $13 \cdot 3$ \\
\hline $16: 0$ & $815 \cdot 6^{a}$ & $19 \cdot 4$ & $719 \cdot 0^{b}$ & $35 \cdot 3$ \\
\hline $18: 0$ & $176 \cdot 5^{a}$ & 9.0 & $163.4^{b}$ & $7 \cdot 6$ \\
\hline$\sum$ SFA & $1283 \cdot 7^{\mathrm{a}}$ & 24.7 & $1109 \cdot 1^{\mathrm{b}}$ & $42 \cdot 7$ \\
\hline $16: 1$ & $436 \cdot 2^{a}$ & 20.2 & $346 \cdot 8^{\mathrm{b}}$ & 25.0 \\
\hline $18: 1$ & $1382 \cdot 4^{\mathrm{a}}$ & 39.5 & $1149 \cdot 4^{b}$ & $46 \cdot 2$ \\
\hline $20: 1$ & $140 \cdot 9^{a}$ & 31.5 & $71.9^{\mathrm{b}}$ & $42 \cdot 7$ \\
\hline $22: 1$ & $74 \cdot 3^{a}$ & 48.9 & $49 \cdot 2^{a}$ & 28.9 \\
\hline$\sum$ MUFA & $2042 \cdot 0^{a}$ & 89.1 & $1620 \cdot 5^{\mathrm{b}}$ & 28.2 \\
\hline $18: 2 n-6$ & $384.0^{\mathrm{a}}$ & 9.5 & $319 \cdot 1^{\mathrm{b}}$ & $17 \cdot 8$ \\
\hline $20: 2 n-6$ & $15 \cdot 9^{\mathrm{a}}$ & 8.9 & $6 \cdot 5^{\mathrm{a}}$ & 8.9 \\
\hline $20: 4 n-6$ & $62 \cdot 0^{\mathrm{a}}$ & $6 \cdot 4$ & $56 \cdot 3^{\mathrm{a}}$ & 6.9 \\
\hline $18: 3 n-3$ & $77 \cdot 9^{\mathrm{a}}$ & 3.6 & $60 \cdot 2^{\mathrm{b}}$ & 5.4 \\
\hline $18: 4 n-3$ & $57.9^{\mathrm{a}}$ & 4.5 & $42 \cdot 0^{\mathrm{b}}$ & 4.7 \\
\hline $20: 4 n-3$ & $42 \cdot 0^{\mathrm{a}}$ & 23.5 & $31 \cdot 4^{\mathrm{a}}$ & 17.9 \\
\hline $20: 5 n-3$ & $311.9^{a}$ & 30.3 & $243 \cdot 2^{b}$ & 35.3 \\
\hline $22: 5 n-3$ & $203 \cdot 8^{a}$ & $15 \cdot 3$ & $122 \cdot 4^{b}$ & $70 \cdot 3$ \\
\hline $22: 6 n-3$ & $968 \cdot 1^{\mathrm{a}}$ & 98.6 & $819 \cdot 8^{a}$ & $127 \cdot 7$ \\
\hline$\sum$ PUFA & $2259.0^{\mathrm{a}}$ & $100 \cdot 4$ & $1781 \cdot 3^{\mathrm{b}}$ & $104 \cdot 2$ \\
\hline$\sum n-3$ & $1696 \cdot 0^{\mathrm{a}}$ & 121.6 & $1340 \cdot 0^{\mathrm{b}}$ & 134.3 \\
\hline$\sum n-6$ & $497 \cdot 4^{\mathrm{a}}$ & $13 \cdot 8$ & $396 \cdot 1^{\mathrm{b}}$ & $27 \cdot 9$ \\
\hline$\sum n-3: \sum n-6$ & $3 \cdot 4^{\mathrm{a}}$ & 0.3 & $3 \cdot 4^{\mathrm{a}}$ & 0.6 \\
\hline
\end{tabular}

Table 2. Distribution of main lipid classes (\%) in raw and grilled gilthead seabream before (initial) and after digestion (bioaccessible)

\begin{tabular}{lccccc}
\hline & & \multicolumn{4}{c}{ Lipid classes } \\
\cline { 3 - 6 } Culinary process & Initial $v$. bioaccessible & TAG & MAG & NEFA & PL \\
\hline \multirow{2}{*}{ Raw } & Initial & 85.4 & - & 4.3 & 3.8 \\
& Bioaccessible & - & 1.5 & 86.2 & 1.0 \\
Grilled & Initial & 87.6 & - & 2.2 & 4.8 \\
& Bioaccessible & - & 2.1 & 84.3 & 0.8 \\
\hline
\end{tabular}

MAG, monoacylglycerol; PL, phospholipids.

These results are compatible with values reported in previous studies in gilthead seabream ${ }^{(23-25)}$ and in salmon ${ }^{(8,26)}$. TAG are always the most abundant class in fish containing more than $5 \%$ fat, comprising $90 \%$ of the total lipid content ${ }^{(8)}$. On the other hand, NEFA were not detected in salmon ${ }^{(8)}$. Nevertheless, their content in seabream was low, as expected in a non-hydrolysed fish fat fraction. Moreover, given the nature of grilling as a culinary treatment ${ }^{(13)}$, no important change in lipid class composition was within expectations.

Fatty acid profile. The FA profiles of the raw and grilled seabream muscles are displayed in Table 1, and the specific profiles of each lipid class are shown in Table 3.

For raw and grilled fish, PUFA were the most abundant FA group, followed by MUFA and SFA. This distribution was richer in PUFA than that of other farmed fish species such as salmon ${ }^{(8)}$, but within the PUFA range found in other seabream studies ${ }^{(27)}$. The $n-3$ PUFA represented a much larger share of the total compared with the $n-6$ PUFA, yielding a $n-3: n-6$ ratio higher than $1-3.4(\mathrm{sD} 0.3$ ) and 3.4 (SD 0.6) for raw and grilled fish, respectively. This ratio was also higher than that calculated for gilthead seabream fed a reference diet in another study (see the Fish samples section) ${ }^{(27)}$, and even for seabream in an integrated aquaculture system (see the Statistics section) ${ }^{(23)}$. The most abundant FA in fat extracted from seabream was oleic acid $(18: 1)$, which contributed almost to a fourth of the total lipid content. This finding is also in accordance with those of a previous study ${ }^{(27)}$, showing that oleic acid level was the highest (39\% of total FA) among all in farmed seabream muscle. The other FA had the following abundance order: DHA $(22: 6 n-3)>$ palmitic acid $(16: 0)>$ palmitoleic acid $(16: 1)>$ linoleic acid (18:2n-6) > EPA (20:5n-3), all exceeding $200 \mathrm{mg} / 100 \mathrm{~g}$ in both raw and grilled fish. These results are significantly different from those reported for other farmed fish ${ }^{(23)}$, as palmitic and linoleic acids were more abundant than DHA in seabream reared in intensive and semi-intensive systems. Furthermore, eicosenoic acid $(20: 1)$ content was similar to that of the current study's seabream ${ }^{(23)}$. These differences are more related to the particular feed used in rearing farmed seabream.

The statistical differences between FA concentrations in raw and grilled seabream muscles could be ascribed to fat variations with culinary treatment. There was no indication of $n-3$ PUFA (the most labile FA) loss as a result of thermal degradation. This thermal stability even with a drastic cooking procedure such as grilling has been reported previously ${ }^{(8,13,28)}$. Hence, it can be stated that potentially deleterious reactions such as oxidation were not too important ${ }^{(29)}$

In addition, for instance, a meal of $160 \mathrm{~g}$ of grilled seabream muscle may provide $1701 \mathrm{mg}$ of EPA + DHA, which means that a daily meal of grilled seabream warrants more than three times the recommended daily intake of $\mathrm{EPA}+\mathrm{DHA}(500 \mathrm{mg} / \mathrm{d})$ according to the American Heart Association ${ }^{(30)}$.

The amount of linoleic acid and MUFA in farmed seabream is higher compared with wild seabream ${ }^{(31)}$; however, in the case of MUFA, values are lower compared with other reported farmed gilthead seabreams ${ }^{(27)}$. It should be stressed that, given the fact that high FA levels before digestion do not ensure a high intestinal absorption of these lipids, a bioaccessibility study is warranted (see below).

A deeper analysis is rendered possible with the knowledge of the relative FA profile of each main lipid class in raw and grilled seabream before digestion. This means a study of the FA composition of TAG, NEFA and PL (Table 2). In general, for both raw and grilled seabream, the FA composition of the PL was different from that of TAG and NEFA (Table 3). Indeed, the PL fraction was richer in PUFA, particularly $n-3$ PUFA, and poorer in MUFA. The $n-3: n-6$ ratio increased from $2 \cdot 8-3 \cdot 0$ in TAG and NEFA to $4 \cdot 0-4 \cdot 3$ in PL. In addition, palmitic acid and DHA were more concentrated and myristic (14:0), palmitoleic, oleic and linoleic acids were less concentrated in PL. In some cases, such as palmitic, palmitoleic, oleic and linoleic acids, the NEFA fraction occupied an intermediate position with no difference with respect to both TAG and PL.

These results agree with the literature on FA composition of farmed fish lipid classes ${ }^{(32-36)}$, as such previous studies have 
Table 3. Fatty acid profile (\%) of the main lipid classes of raw and grilled gilthead seabream (Averages and standard deviations)

\begin{tabular}{|c|c|c|c|c|c|c|c|c|c|c|c|c|}
\hline \multirow[b]{3}{*}{ Fatty acids } & \multicolumn{6}{|c|}{ Raw fish - lipid classes } & \multicolumn{6}{|c|}{ Grilled fish - lipid classes } \\
\hline & \multicolumn{2}{|c|}{ TAG } & \multicolumn{2}{|c|}{ NEFA } & \multicolumn{2}{|c|}{$\mathrm{PL}$} & \multicolumn{2}{|c|}{ TAG } & \multicolumn{2}{|c|}{ NEFA } & \multicolumn{2}{|c|}{ PL } \\
\hline & Average & SD & Average & SD & Average & $\mathrm{SD}$ & Average & $\mathrm{SD}$ & Average & SD & Average & SD \\
\hline $14: 0$ & $3.8^{\mathrm{a}, \mathrm{A}}$ & 0.0 & $2 \cdot 7^{\mathrm{a}, \mathrm{b}, \mathrm{A}}$ & 0.3 & $1 \cdot 0^{\mathrm{b}, \mathrm{A}}$ & $0 \cdot 1$ & $3 \cdot 7^{\mathrm{a}, \mathrm{A}}$ & $0 \cdot 1$ & $3 \cdot 0^{\mathrm{a}, \mathrm{b}, \mathrm{A}}$ & 0.1 & $1 \cdot 0^{\mathrm{b}, \mathrm{A}}$ & 0.3 \\
\hline $16: 0$ & $14 \cdot 1^{\mathrm{a}, \mathrm{A}}$ & 0.2 & $12 \cdot 6^{\mathrm{a}, \mathrm{b}, \mathrm{A}}$ & $9 \cdot 2$ & $21 \cdot 7^{\mathrm{b}, \mathrm{A}}$ & 0.6 & $14 \cdot 1^{\mathrm{a}, \mathrm{A}}$ & 0.1 & $20 \cdot 6^{\mathrm{a}, \mathrm{b}, \mathrm{A}}$ & 1.9 & $21 \cdot 0^{\mathrm{b}, \mathrm{a}, \mathrm{A}}$ & 0.9 \\
\hline $18: 0$ & $2 \cdot 8^{\mathrm{a}, \mathrm{A}}$ & 0.1 & $7 \cdot 1^{\mathrm{b}, \mathrm{A}}$ & 0.8 & $4 \cdot 8^{\mathrm{a}, \mathrm{b}, \mathrm{A}}$ & $4 \cdot 2$ & $1.9^{\mathrm{a}, \mathrm{A}}$ & 1.6 & $9 \cdot 7^{\mathrm{b}, \mathrm{B}}$ & $1 \cdot 1$ & $4 \cdot 6^{\mathrm{a}, \mathrm{b}, \mathrm{A}}$ & 4.0 \\
\hline$\sum$ SFA & $22 \cdot 0^{\mathrm{a}, \mathrm{A}}$ & 0.3 & $23 \cdot 8^{\mathrm{a}, \mathrm{A}}$ & $8 \cdot 8$ & $28 \cdot 4^{\mathrm{a}, \mathrm{A}}$ & 4.0 & $20 \cdot 8^{\mathrm{a}, \mathrm{A}}$ & 1.5 & $35 \cdot 2^{\mathrm{b}, \mathrm{A}}$ & 2.6 & $27 \cdot 3^{\mathrm{a}, \mathrm{b}, \mathrm{A}}$ & 3.6 \\
\hline $16: 1$ & $7 \cdot 9^{\mathrm{a}, \mathrm{A}}$ & 0.1 & $6 \cdot 0^{\mathrm{a}, \mathrm{b}, \mathrm{A}}$ & 0.7 & $2 \cdot 1^{\mathrm{b}, \mathrm{A}}$ & 0.3 & $5 \cdot 4^{\mathrm{a}, \mathrm{A}}$ & $4 \cdot 1$ & $5 \cdot 0^{\mathrm{a}, \mathrm{b}, \mathrm{A}}$ & 0.9 & $2 \cdot 1^{\mathrm{b}, \mathrm{A}}$ & 0.4 \\
\hline $18: 1$ & $25 \cdot 2^{\mathrm{a}, \mathrm{A}}$ & 0.6 & $25 \cdot 2^{\mathrm{a}, \mathrm{b}, \mathrm{A}}$ & $4 \cdot 1$ & $14 \cdot 1^{\mathrm{b}, \mathrm{A}}$ & 0.4 & $25 \cdot 5^{\mathrm{a}, \mathrm{A}}$ & 0.6 & $20 \cdot 5^{\mathrm{a}, \mathrm{b}, \mathrm{A}}$ & 0.7 & $15 \cdot 4^{\mathrm{b}, \mathrm{B}}$ & 0.6 \\
\hline $20: 1$ & $1.9^{\mathrm{a}, \mathrm{A}}$ & 1.6 & $2 \cdot 0^{\mathrm{a}, \mathrm{b}, \mathrm{A}}$ & 0.6 & $1.0^{\mathrm{b}, \mathrm{A}}$ & 0.1 & $2 \cdot 9^{\mathrm{a}, \mathrm{A}}$ & 0.1 & $1.5^{\mathrm{a}, \mathrm{b}, \mathrm{A}}$ & 0.7 & $1.2^{\mathrm{b}, \mathrm{A}}$ & 0.2 \\
\hline $22: 1$ & $2 \cdot 1^{\mathrm{a}, \mathrm{A}}$ & 0.1 & $1 \cdot 3^{\mathrm{a}, \mathrm{b}, \mathrm{A}}$ & 0.6 & $0.5^{\mathrm{b}, \mathrm{A}}$ & 0.0 & $2 \cdot 1^{\mathrm{a}, \mathrm{A}}$ & 0.1 & $0 \cdot 4^{\mathrm{a}, \mathrm{b}, \mathrm{A}}$ & 0.3 & $0.1^{\mathrm{b}, \mathrm{B}}$ & 0.1 \\
\hline$\sum$ MUFA & $37 \cdot 8^{\mathrm{a}, \mathrm{A}}$ & $2 \cdot 1$ & $34.9^{\mathrm{a}, \mathrm{b}, \mathrm{A}}$ & 4.7 & $17 \cdot 9^{\mathrm{b}, \mathrm{A}}$ & 0.9 & $36 \cdot 5^{\mathrm{a}, \mathrm{A}}$ & $4 \cdot 3$ & $27 \cdot 8^{\mathrm{a}, \mathrm{b}, \mathrm{A}}$ & $2 \cdot 2$ & $19 \cdot 0^{\mathrm{b}, \mathrm{A}}$ & 1.0 \\
\hline $18: 2 n-6$ & $6 \cdot 7^{\mathrm{a}, \mathrm{A}}$ & 0.1 & $6 \cdot 5^{\mathrm{a}, \mathrm{b}, \mathrm{A}}$ & $1 \cdot 1$ & $3 \cdot 9^{\mathrm{b}, \mathrm{A}}$ & 0.3 & $6 \cdot 7^{\mathrm{a}, \mathrm{A}}$ & 0.1 & $4 \cdot 8^{\mathrm{a}, \mathrm{b}, \mathrm{A}}$ & 0.1 & $4 \cdot 2^{\mathrm{b}, \mathrm{A}}$ & 0.2 \\
\hline $20: 2 n-6$ & $0 \cdot 3^{\mathrm{a}, \mathrm{A}}$ & 0.0 & $0.3^{\mathrm{a}, \mathrm{A}}$ & 0.3 & $0.3^{\mathrm{a}, \mathrm{A}}$ & 0.0 & $0.3^{\mathrm{a}, \mathrm{A}}$ & 0.1 & $0.2^{\mathrm{a}, \mathrm{A}}$ & 0.2 & $0 \cdot 3^{\mathrm{a}, \mathrm{A}}$ & 0.0 \\
\hline $20: 4 n-6$ & $0.6^{\mathrm{a}, \mathrm{A}}$ & 0.4 & $1 \cdot 2^{\mathrm{a}, \mathrm{A}}$ & 0.3 & $2 \cdot 9^{\mathrm{b}, \mathrm{A}}$ & 0.2 & $0.9^{\mathrm{a}, \mathrm{A}}$ & 0.0 & $0.7^{\mathrm{a}, \mathrm{A}}$ & 0.1 & $3.0^{\mathrm{b}, \mathrm{A}}$ & 0.1 \\
\hline $18: 3 n-3$ & $1.4^{\mathrm{a}, \mathrm{A}}$ & 0.0 & $1 \cdot 2^{\mathrm{a}, \mathrm{b}, \mathrm{A}}$ & 0.2 & $0.4^{\mathrm{b}, \mathrm{A}}$ & 0.0 & $1 \cdot 4^{\mathrm{a}, \mathrm{A}}$ & 0.0 & $0 \cdot 8^{\mathrm{a}, \mathrm{b}, \mathrm{B}}$ & 0.1 & $0.4^{\mathrm{b}, \mathrm{A}}$ & 0.1 \\
\hline $18: 4 n-3$ & $1.0^{\mathrm{a}, \mathrm{A}}$ & 0.0 & $0.6^{\mathrm{a}, \mathrm{b}, \mathrm{A}}$ & 0.2 & $0.1^{\mathrm{b}, \mathrm{A}}$ & 0.0 & $1.0^{\mathrm{a}, \mathrm{A}}$ & 0.0 & $0.5^{\mathrm{a}, \mathrm{b}, \mathrm{A}}$ & 0.2 & $0.2^{\mathrm{b}, \mathrm{A}}$ & 0.1 \\
\hline $20: 4 n-3$ & $0.9^{\mathrm{a}, \mathrm{b}, \mathrm{A}}$ & 0.0 & $2 \cdot 8^{\mathrm{a}, \mathrm{A}}$ & 1.3 & $0.4^{\mathrm{b}, \mathrm{A}}$ & 0.0 & $0 \cdot 6^{\mathrm{a}, \mathrm{b}, \mathrm{A}}$ & 0.5 & $4 \cdot 3^{\mathrm{a}, \mathrm{A}}$ & $1 . \overline{7}$ & $0.5^{\mathrm{b}, \mathrm{A}}$ & 0.0 \\
\hline $20: 5 n-3$ & $5 \cdot 0^{\mathrm{a}, \mathrm{A}}$ & 0.1 & $7 \cdot 7^{\mathrm{a}, \mathrm{A}}$ & 2.3 & $5 \cdot 6^{\mathrm{a}, \mathrm{A}}$ & 0.1 & $4 \cdot 8^{\mathrm{a}, \mathrm{A}}$ & 0.1 & $3 \cdot 0^{\mathrm{a}, \mathrm{B}}$ & 0.8 & $5 \cdot 8^{\mathrm{a}, \mathrm{A}}$ & 0.2 \\
\hline $22: 5 n-3$ & $3 \cdot 4^{\mathrm{a}, \mathrm{A}}$ & 0.0 & $2 \cdot 3^{\mathrm{b}, \mathrm{A}}$ & 0.5 & $2 \cdot 8^{\mathrm{a}, \mathrm{b}, \mathrm{A}}$ & 0.0 & $3 \cdot 4^{\mathrm{a}, \mathrm{A}}$ & 0.0 & $0.8^{\mathrm{b}, \mathrm{A}}$ & 0.8 & $2 \cdot 9^{\mathrm{a}, \mathrm{b}, \mathrm{A}}$ & 0.1 \\
\hline $22: 6 n-3$ & $11.9^{\mathrm{a}, \mathrm{b}, \mathrm{A}}$ & $5 \cdot 1$ & $9 \cdot 0^{\mathrm{a}, \mathrm{A}}$ & 1.6 & $29 \cdot 6^{\mathrm{b}, \mathrm{A}}$ & 0.3 & $13 \cdot 0^{\mathrm{a}, \mathrm{b}, \mathrm{A}}$ & 3.9 & $5 \cdot 1^{\mathrm{a}, \mathrm{A}}$ & 4.5 & $26 \cdot 1^{\mathrm{b}, \mathrm{A}}$ & 3.9 \\
\hline$\sum$ PUFA & $33 \cdot 3^{\mathrm{a}, \mathrm{A}}$ & 5.9 & $33 \cdot 7^{\mathrm{a}, \mathrm{A}}$ & 5.9 & $49 \cdot 5^{\mathrm{b}, \mathrm{A}}$ & 0.9 & $34.5^{\mathrm{a}, \mathrm{A}}$ & 3.6 & $22 \cdot 8^{\mathrm{a}, \mathrm{A}}$ & 5.4 & $46 \cdot 1^{\mathrm{b}, \mathrm{A}}$ & 4.4 \\
\hline$\sum n-3$ & $24 \cdot 3^{\mathrm{a}, \mathrm{A}}$ & 5.6 & $24 \cdot 8^{\mathrm{a}, \mathrm{A}}$ & $4 \cdot 1$ & $39 \cdot 9^{\mathrm{b}, \mathrm{A}}$ & 0.4 & $24 \cdot 9^{\mathrm{a}, \mathrm{A}}$ & 3.6 & $16 \cdot 8^{\mathrm{a}, \mathrm{A}}$ & 5.6 & $36 \cdot 6^{\mathrm{b}, \mathrm{A}}$ & 4.4 \\
\hline$\sum n-6$ & $8 \cdot 6^{\mathrm{a}, \mathrm{b}, \mathrm{A}}$ & 0.6 & $8 \cdot 4^{\mathrm{a}, \mathrm{A}}$ & 1.8 & $9 \cdot 4^{\mathrm{b}, \mathrm{A}}$ & 0.4 & $9 \cdot 0^{\mathrm{a}, \mathrm{bA}}$ & 0.2 & $5 \cdot 8^{\mathrm{a}, \mathrm{A}}$ & 0.2 & $9 \cdot 2^{\mathrm{b}, \mathrm{a}, \mathrm{A}}$ & 0.1 \\
\hline$\sum n-3: \sum n-6$ & $2 \cdot 8^{\mathrm{a}, \mathrm{A}}$ & 0.5 & $3 \cdot 0^{\mathrm{a}, \mathrm{A}}$ & 0.2 & $4 \cdot 3^{\mathrm{b}, \mathrm{A}}$ & 0.2 & $2 \cdot 8^{\mathrm{a}, \mathrm{A}}$ & 0.4 & $2 \cdot 9^{\mathrm{a}, \mathrm{A}}$ & 1.0 & $4 \cdot 0^{\mathrm{b}, \mathrm{A}}$ & 0.5 \\
\hline
\end{tabular}

$\mathrm{PL}$, phospholipids.

${ }^{\mathrm{a}, \mathrm{b}}$ For each culinary treatment, different unlike lowercase superscript letters within a row correspond to statistical differences $(P<0.05)$.

${ }^{A}, \mathrm{~B}$ For each lipid class, different unlike uppercase superscript letters within a row correspond to statistical differences $(P<0.05)$.

also reported higher palmitic acid, DHA and $n$-3 PUFA contents and lower myristic, palmitoleic, oleic and linoleic acid contents in PL. However, contrary to some reports ${ }^{(33,35)}$, there was no higher EPA content in PL than in other classes. This may be explained by the utilisation of EPA as a substrate for eicosanoid biosynthesis in marine fish species ${ }^{(37,38)}$, thereby reducing its structural role in PL. TAG FA composition largely reflects the composition of the diet, which is typically richer in MUFA and linoleic acid because of the high portion of vegetable meal and vegetable oil used in the making of farmed fish feeds ${ }^{(35)}$. This is a consequence of the role of TAG as storage fat in fish. On the other hand, PL are structural lipids in the membranes of fish cells and they require specific, bound FA in order to function properly. For example, PL rich in DHA and other $n$-3 PUFA provide sufficient plasticity to cope with pressure and temperature changes in the water environment ${ }^{(36)}$.

Finally, it should be remarked that there were no important differences between the FA profiles of the lipid classes of raw and grilled seabream muscles. Hence, grilling did not cause any fundamental shift in the distribution of the FA. As this culinary treatment does not involve any major fat addition ${ }^{(13)}$, as with frying, such absence of differences can be interpreted as further evidence of lipid thermal stability.

\section{Bioaccessibility}

Protein and lipid fractions. The level of protein hydrolysis during in vitro digestion is a measure of the efficiency of the used method. It was found that after in vitro digestion of seabream, protein recovery (\%) in the bioaccessible fraction was $98.5 \%$ for raw and was slightly lower, $94.6 \%$, for grilled fish. Therefore, it can be claimed that almost all fish proteins were hydrolysed in raw and grilled seabream. The lower protein bioaccessibility in grilled salmon could be due to the harsh thermal treatment ${ }^{(39)}$. Indeed, heating leads to protein denaturation and digestibility reduction owing to the generation of covalent bonds between polypeptide chains ${ }^{(39)}$.

With regard to digestion of the lipid fraction (Table 4), the bioaccessible percentages, although high, were lower than that for protein, 80 (SD 5)\% for raw and 74 (SD 8) \% for grilled seabream, respectively. Nonetheless, lipid digestion was quite thorough, given the disappearance of the TAG band in TLC and the large increase in the NEFA portion (Table 2). PL were also digested, but some remained non-hydrolysed. Moreover, the reduction in lipid bioaccessibility with grilling was statistically significant $(P<0.05)$ (Table 4$)$. This seems to indicate that the protein aggregates formed as a result of cross-linking reactions induced by grilling ${ }^{(39)}$ were effective in trapping a significant portion of the lipids, thus reducing lipid bioaccessibility. A similar bioaccessibility reduction with grilling has been observed for farmed salmon ${ }^{(8)}$.

Fatty acid composition. The bioaccessibility levels for each FA in raw and grilled seabream muscles are presented in Table 4. Bioaccessibility was calculated for the most abundant FA.

FA bioaccessibility varied widely depending on the particular FA and the culinary treatment, ranging from 82.5 (SD 6.6)\% for 
Table 4. Lipid and fatty acid bioaccessibility (\%) in raw and grilled gilthead seabream

(Averages and standard deviations)

\begin{tabular}{|c|c|c|c|c|}
\hline & \multicolumn{4}{|c|}{ Bioaccessibility (\%) } \\
\hline & \multicolumn{2}{|c|}{ Raw fish } & \multicolumn{2}{|c|}{ Grilled fish } \\
\hline & Average & SD & Average & SD \\
\hline Lipid & $80 \cdot 2^{A}$ & 4.5 & $73 \cdot 6^{\mathrm{B}}$ & $8 \cdot 3$ \\
\hline \multicolumn{5}{|l|}{ Fatty acids } \\
\hline $14: 0$ & $82 \cdot 5^{\mathrm{a}, \mathrm{A}}$ & 6.6 & $77 \cdot 6^{\mathrm{a}, \mathrm{A}}$ & 3.5 \\
\hline $16: 0$ & $79 \cdot 4^{\mathrm{a}, \mathrm{A}}$ & 6.4 & $78 \cdot 8^{\mathrm{a}, \mathrm{A}}$ & 4.9 \\
\hline $18: 0$ & $68 \cdot 6^{\mathrm{b}, \mathrm{A}}$ & 9.3 & $78 \cdot 3^{\mathrm{a}, \mathrm{A}}$ & $4 \cdot 3$ \\
\hline$\sum$ SFA & $79 \cdot 3^{\mathrm{a}, \mathrm{A}}$ & 6.8 & $78 \cdot 5^{\mathrm{a}, \mathrm{A}}$ & $5 \cdot 1$ \\
\hline $16: 1$ & $82 \cdot 2^{\mathrm{a}, \mathrm{A}}$ & 3.9 & $76 \cdot 3^{\mathrm{a}, \mathrm{b}, \mathrm{A}}$ & 1.6 \\
\hline $18: 1$ & $81 \cdot 7^{\mathrm{a}, \mathrm{A}}$ & 0.7 & $70 \cdot 2^{a, b, B}$ & 1.6 \\
\hline$\sum$ MUFA & $84 \cdot 0^{\mathrm{a}, \mathrm{A}}$ & 0.2 & $75 \cdot 5^{\mathrm{a}, \mathrm{b}, \mathrm{A}}$ & 3.2 \\
\hline $18: 2 n-6$ & $66 \cdot 4^{\mathrm{b}, \mathrm{A}}$ & $2 \cdot 0$ & $51 \cdot 4^{\mathrm{b}, \mathrm{B}}$ & 3.2 \\
\hline $18: 3 n-3$ & $78 \cdot 0^{\mathrm{a}, \mathrm{A}}$ & $1 \cdot 1$ & $68 \cdot 4^{\mathrm{a}, \mathrm{b}, \mathrm{B}}$ & 1.0 \\
\hline $18: 4 n-3$ & $77 \cdot 7^{\mathrm{a}, \mathrm{A}}$ & 1.5 & $69 \cdot 0^{\mathrm{a}, \mathrm{b}, \mathrm{B}}$ & 1.2 \\
\hline $20: 5 n-3$ & $72 \cdot 0^{\mathrm{b}, \mathrm{A}}$ & 2.9 & $58 \cdot 3^{\mathrm{b}, \mathrm{B}}$ & 0.6 \\
\hline $22: 5 n-3$ & $79 \cdot 4^{\mathrm{a}, \mathrm{A}}$ & 6.7 & $81.9^{\mathrm{a}, \mathrm{A}}$ & 0.6 \\
\hline $22: 6 n-3$ & $73 \cdot 0^{\mathrm{b}, \mathrm{A}}$ & 5.5 & $54 \cdot 9^{\mathrm{b}, \mathrm{B}}$ & 3.4 \\
\hline$\sum$ PUFA & $72 \cdot 3^{\mathrm{b}, \mathrm{A}}$ & 3.7 & $58 \cdot 2^{\mathrm{b}, \mathrm{B}}$ & $2 \cdot 8$ \\
\hline$\sum n-3$ & $74.0^{\mathrm{b}, \mathrm{A}}$ & 4.6 & $59 \cdot 0^{\mathrm{b}, \mathrm{B}}$ & 2.5 \\
\hline$\sum n-6$ & $61 \cdot 7^{\mathrm{b}, \mathrm{A}}$ & 1.5 & $49 \cdot 6^{\mathrm{b}, \mathrm{B}}$ & $6 \cdot 6$ \\
\hline
\end{tabular}

${ }^{a, b}$ For each culinary treatment, different unlike lowercase superscript letters within a column correspond to statistical differences $(P<0.05)$ between fatty acids.

$A, B$ For lipid content and each fatty acid, different unlike uppercase superscript letters within a row correspond to statistical differences $(P<0.05)$.

myristic acid in raw seabream to 51.4 (SD 3.2 )\% for linoleic acid in grilled seabream. A more systematic review of the results showed that SFA and MUFA were more bioaccessible (76-84\%) than PUFA (58-72\%) in raw and grilled seabream. This was also found in a previous study with salmon when grilled $^{(8)}$. The differences between bioaccessible $n-3$ PUFA (59-74\%) and n-6 PUFA (50-62\%) were not statistically significant. Within each main FA group, there were no major trends associated with FA chain length, with the exception of a reduction in FA bioaccessibility with stearic acid (18:0), a lengthier SFA, in raw fish. This effect of FA chain length in the SFA group is different from that observed for salmon ${ }^{(8)}$, but is supported by other studies (although related to different food matrices), which indicate more efficient absorption into the bloodstream of SCFA and medium-chain FA ${ }^{(40)}$

In some isolated cases, a reduction in bioaccessibility with higher levels of unsaturation was observed. For example, the pair oleic-linoleic acids, both with 18 carbons, 70-82 v. 51-66\%, supported this observation. EPA and DHA bioaccessibility (55-73\%) was clearly below that of all other main SFA and MUFA (76-83\%), with the exception of stearic acid in raw fish and oleic acid in grilled fish. Concerning this effect of the unsaturation level, it is possible that lipases are less able to hydrolyse more unsaturated FA, thereby contributing to a reduction in lipid bioaccessibility. This explanation is based on a recent study reporting that porcine pancreatic lipase (PPL) preferentially hydrolyses FA whose first double bond from the ester linkage is farther from the ester moiety ${ }^{(41)}$. Precisely, less unsaturated FA have in average a double bond not so close to the ester linkage. According to this hypothesis, less hydrolysis for highly unsaturated FA would entail a higher portion of these in the form of TAG, DAG and MAG, which are larger molecules and may be retained in the non-digested part.

The effect of culinary treatment on fatty acid bioaccessibility. A comparison between the bioaccessibility of FA in raw and grilled seabream muscles is given in Table 4 .

The reduction in lipid bioaccessibility (see above) as a result of grilling is also replicated by several specific FA. This variation was mainly detected for total PUFA, $n-3$ PUFA and n-6 PUFA. In particular, the bioaccessibility of oleic, linoleic, $\alpha$-linolenic (18:3n-3), EPA and DHA was affected by the cooking method. On the other hand, palmitoleic acid, DPA (22:5n-3) as well as none of the SFA displayed a significant variation in bioaccessibility. It can be hypothesised that the protein aggregates formed as a result of cross-linking reactions induced by grilling $^{(39)}$ were more effective in withholding PUFA than SFA. The higher polarity associated with double bonds may make the PUFA more prone to get attached to the protein aggregates and be partially removed from the bioaccessible fraction. However, these bioaccessibility contrasts between different FA were not observed in a previous study with salmon ${ }^{(8)}$. Therefore, given the novelty of these bioaccessibility studies with lipids, further experimental studies are required.

The effect of lipid class on fatty acid bioaccessibility. For a better understanding of the bioaccessibility results, it is important to perform a more detailed analysis of the FA profiles and take into account their variation between different lipid classes in the bioaccessible fractions of raw and grilled seabream (Table 5).

First, it must be mentioned that the in vitro digestion caused a thorough alteration in lipid class distribution (Table 2). The NEFA were the main lipid class in the bioaccessible part of both raw ( $86.2 \%$ of total fat) and grilled seabream ( $84.3 \%$ of total fat). This equates to a deep change with respect to fat class distribution in seabream before digestion. Besides, TAG were not detectable, and a scarce amount of MAG was detected after digestion, $1-2 \%$. PL were partially hydrolysed.

Comparable results have been delivered by other studies using in vitro digestive methodologies ${ }^{(8,42)}$. Nonetheless, other studies have reported only partial TAG hydrolysis ${ }^{(43)}$. These discrepancies may be the consequence of technical details such as the relation between fat substrate amount and lipase quantity. Contrary to previous studies ${ }^{(8)}$, PL hydrolysis was achieved; however, it was not complete. The absence of total PL hydrolysis warrants further study, as no important deleterious effect on the release of NEFA from the PL in comparison with TAG has been observed ${ }^{(44)}$.

These results show differences between the FA profile of NEFA, MAG and PL in the bioaccessible fraction of both raw and grilled seabream. Typically, the MAG had a FA composition more similar to that of PL, whereas NEFA were different from these two classes. That is, although the total SFA in bioaccessible raw fish and $n-3$ PUFA in bioaccessible grilled fish were higher in the MAG and PL classes, total MUFA and $n-6$ PUFA were lower in these lipid classes. In particular, differences were found for oleic and linoleic acids (lower in MAG and PL) and DHA (higher in MAG and PL). Myristic and palmitic acids were particularly high 
Table 5. Fatty acid profile (\%) of the main lipid classes in the bioaccessible fraction from raw and grilled gilthead seabream (Averages and standard deviations)

\begin{tabular}{|c|c|c|c|c|c|c|c|c|c|c|c|c|}
\hline \multirow[b]{4}{*}{ Fatty acids } & \multicolumn{12}{|c|}{ Bioaccessible fraction } \\
\hline & \multicolumn{6}{|c|}{ Raw fish - lipid classes } & \multicolumn{6}{|c|}{ Grilled fish - lipid classes } \\
\hline & \multicolumn{2}{|c|}{ NEFA } & \multicolumn{2}{|c|}{ MAG } & \multicolumn{2}{|c|}{$\mathrm{PL}$} & \multicolumn{2}{|c|}{ NEFA } & \multicolumn{2}{|c|}{ MAG } & \multicolumn{2}{|c|}{ PL } \\
\hline & Average & SD & Average & SD & Average & SD & Average & SD & Average & SD & Average & SD \\
\hline $14: 0$ & $2 \cdot 2^{\mathrm{a}, \mathrm{A}}$ & 0.0 & $8 \cdot 1^{\mathrm{b}, \mathrm{A}}$ & 0.1 & $2 \cdot 9^{\mathrm{a}, \mathrm{A} \star}$ & 0.5 & $2 \cdot 4^{\mathrm{a}, \mathrm{A} \star}$ & 0.0 & $7 \cdot 2^{\mathrm{b}, \mathrm{A}}$ & 1.0 & $2 \cdot 3^{\mathrm{a}, \mathrm{A} *}$ & 0.3 \\
\hline $16: 0$ & $15 \cdot 0^{\mathrm{a}, \mathrm{A}}$ & $1 \cdot 1$ & $23 \cdot 0^{\mathrm{b}, \mathrm{A}}$ & 0.3 & $18 \cdot 9^{\mathrm{a}, \mathrm{b}, \mathrm{A} *}$ & $1 \cdot 2$ & $18 \cdot 7^{\mathrm{a}, \mathrm{A}}$ & 1.3 & $23 \cdot 5^{a, A}$ & $1 \cdot 2$ & $21 \cdot 9^{\mathrm{a}, \mathrm{A}}$ & $2 \cdot 3$ \\
\hline $18: 0$ & $5 \cdot 5^{\mathrm{a}, \mathrm{A}}$ & 0.7 & $1.9^{\mathrm{b}, \mathrm{A}}$ & 0.0 & $8 \cdot 5^{\mathrm{c}, \mathrm{A}}$ & 0.0 & $7 \cdot 2^{\mathrm{a}, \mathrm{A}}$ & 0.6 & $2 \cdot 5^{\mathrm{b}, \mathrm{B}}$ & 0.1 & $8 \cdot 8^{\mathrm{a}, \mathrm{A}}$ & 1.6 \\
\hline$\sum$ SFA & $23 \cdot 8^{\mathrm{a}, \mathrm{A}}$ & 1.7 & $34 \cdot 8^{\mathrm{b}, \mathrm{A}}$ & 0.2 & $31 \cdot 2^{\mathrm{b}, \mathrm{A}}$ & 2.0 & $29 \cdot 4^{\mathrm{a}, \mathrm{A}}$ & 1.9 & $34 \cdot 8^{\mathrm{a}, \mathrm{A}}$ & $2 \cdot 2$ & $33 \cdot 6^{\mathrm{a}, \mathrm{A}}$ & $4 \cdot 0$ \\
\hline $16: 1$ & $6 \cdot 0^{\mathrm{a}, \mathrm{A}}$ & 0.2 & $9 \cdot 1^{\mathrm{b}, \mathrm{A}}$ & 0.0 & $3 \cdot 9^{\mathrm{a}, \mathrm{A}}$ & 1.0 & $5 \cdot 7^{\mathrm{a}, \mathrm{A}}$ & 0.0 & $8 \cdot 4^{\mathrm{b}, \mathrm{A}}$ & 0.7 & $3.0^{\mathrm{c}, \mathrm{A}}$ & 1.0 \\
\hline $18: 1$ & $29 \cdot 2^{a, A}$ & 0.1 & $11.7^{\mathrm{b}, \mathrm{A}}$ & 0.1 & $13 \cdot 6^{\mathrm{b}, \mathrm{A}}$ & 0.8 & $28 \cdot 6^{\mathrm{a}, \mathrm{B} *}$ & 0.2 & $11.9^{\mathrm{b}, \mathrm{A}}$ & 0.2 & $14 \cdot 6^{\mathrm{b}, \mathrm{A}}$ & 0.6 \\
\hline $20: 1$ & $2 \cdot 9^{\mathrm{a}, \mathrm{A}}$ & 0.1 & $1 \cdot 1^{\mathrm{a}, \mathrm{A}}$ & 0.1 & $1 \cdot 1^{\mathrm{a}, \mathrm{A}}$ & 1.0 & $2 \cdot 7^{\mathrm{a}, \mathrm{A}}$ & 0.0 & $1 \cdot 1^{\mathrm{b}, \mathrm{A}}$ & 0.0 & $0.0^{\mathrm{b}, \mathrm{A} *}$ & 0.0 \\
\hline $22: 1$ & $2 \cdot 3^{\mathrm{a}, \mathrm{A}}$ & 0.1 & $0.9^{\mathrm{a}, \mathrm{b}, \mathrm{A}}$ & 0.2 & $0.0^{\mathrm{b}, \mathrm{A}_{*}}$ & 0.0 & $2 \cdot 0^{\mathrm{a}, \mathrm{A}_{*}}$ & 0.1 & $0.8^{\mathrm{a}, \mathrm{b}, \mathrm{A}}$ & 0.2 & $0.0^{\mathrm{b}, \mathrm{A}}$ & 0.0 \\
\hline$\sum$ MUFA & $40 \cdot 6^{\mathrm{a}, \mathrm{A}}$ & 0.2 & $22 \cdot 9^{\mathrm{b}, \mathrm{A}}$ & 0.1 & $18 \cdot 6^{\mathrm{b}, \mathrm{A}}$ & 0.7 & $39 \cdot 1^{\mathrm{a}, \mathrm{B} *}$ & 0.0 & $22 \cdot 3^{\mathrm{b}, \mathrm{A}}$ & 0.3 & $17 \cdot 6^{\mathrm{c}, \mathrm{A}}$ & 1.6 \\
\hline $18: 2 n-6$ & $9 \cdot 3^{\mathrm{a}, \mathrm{A}}$ & 0.3 & $6 \cdot 0^{\mathrm{b}, \mathrm{A}}$ & 0.1 & $4.9^{\mathrm{b}, \mathrm{A}_{*}}$ & 0.0 & $9 \cdot 7^{\mathrm{a}, \mathrm{A}_{\star}}$ & 0.2 & $5 \cdot 9^{\mathrm{b}, \mathrm{A}}$ & 0.1 & $5 \cdot 1^{\mathrm{c}, \mathrm{B} *}$ & 0.1 \\
\hline $20: 2 n-6$ & $0.3^{\mathrm{a}, \mathrm{A}}$ & 0.0 & $0.0^{\mathrm{b}, \mathrm{A}}$ & 0.0 & $0.0^{\mathrm{b}, \mathrm{A} \star}$ & 0.0 & $0 \cdot 2^{\mathrm{a}, \mathrm{A}}$ & 0.2 & $0.0^{\mathrm{a}, \mathrm{A}}$ & 0.0 & $0 \cdot 0^{\mathrm{a}, \mathrm{A} *}$ & 0.0 \\
\hline $20: 4 n-6$ & $2 \cdot 1^{\mathrm{a}, \mathrm{A \star}}$ & 0.1 & $1.0^{\mathrm{a}, \mathrm{A}}$ & 0.0 & $0.8^{\mathrm{a}, \mathrm{A} \star}$ & $1 \cdot 1$ & $2 \cdot 2^{\mathrm{a}, \mathrm{A} \star}$ & 0.1 & $1.0^{\mathrm{b}, \mathrm{A}}$ & 0.1 & $1 \cdot 7^{\mathrm{b}, \mathrm{A} *}$ & 0.1 \\
\hline $18: 3 n-3$ & $1 \cdot 1^{\mathrm{a}, \mathrm{A}}$ & 0.1 & $1 \cdot 3^{\mathrm{a}, \mathrm{A}}$ & 0.0 & $0.7^{\mathrm{a}, \mathrm{A}_{\star}}$ & 0.0 & $0.9^{\mathrm{a}, \mathrm{A}}$ & 0.0 & $1 \cdot 2^{\mathrm{a}, \mathrm{A}}$ & 0.0 & $0.3^{\mathrm{a}, \mathrm{A}}$ & 0.4 \\
\hline $18: 4 n-3$ & $0.5^{\mathrm{a}, \mathrm{A}}$ & 0.1 & $1 \cdot 7^{\mathrm{a}, \mathrm{A}}$ & 0.1 & $0.8^{\mathrm{a}, \mathrm{A}_{\star}}$ & 0.1 & $0 \cdot 4^{\mathrm{a}, \mathrm{A}}$ & 0.0 & $1.5^{\mathrm{a}, \mathrm{A}}$ & 0.1 & $1.0^{\mathrm{a}, \mathrm{A}}$ & 1.0 \\
\hline $20: 4 n-3$ & $0.9^{\mathrm{a}, \mathrm{A}}$ & 0.1 & $0.4^{\mathrm{a}, \mathrm{b}, \mathrm{A}}$ & 0.0 & $0 \cdot 0^{\mathrm{b}, \mathrm{A}_{\star}}$ & 0.0 & $0.7^{\mathrm{a}, \mathrm{A}}$ & 0.0 & $0.4^{\mathrm{a}, \mathrm{A}}$ & 0.0 & $1.9^{\mathrm{a}, \mathrm{A}}$ & 2.6 \\
\hline $20: 5 n-3$ & $4 \cdot 0^{\mathrm{a}, \mathrm{A}}$ & 0.1 & $3 \cdot 8^{\mathrm{a}, \mathrm{A}}$ & 0.1 & $3 \cdot 7^{\mathrm{a}, \mathrm{A}_{\star}}$ & 0.7 & $3 \cdot 1^{\mathrm{a}, \mathrm{B}}$ & 0.2 & $3.7^{\mathrm{a}, \mathrm{A}}$ & 0.4 & $1 \cdot 7^{\mathrm{a}, \mathrm{A}}$ & 2.4 \\
\hline $22: 5 n-3$ & $2 \cdot 4^{\mathrm{a}, \mathrm{A}}$ & 0.2 & $4 \cdot 4^{\mathrm{a}, \mathrm{A}}$ & 0.1 & $1 \cdot 4^{\mathrm{a}, \mathrm{A}}$ & $2 \cdot 0$ & $1 \cdot 8^{\mathrm{a}, \mathrm{A}}$ & 0.2 & $4 \cdot 3^{\mathrm{a}, \mathrm{A}}$ & 0.4 & $1.4^{\mathrm{a}, \mathrm{A}}$ & 2.0 \\
\hline $22: 6 n-3$ & $10 \cdot 4^{\mathrm{a}, \mathrm{A}}$ & 0.8 & $18 \cdot 8^{\mathrm{a}, \mathrm{b}, \mathrm{A}}$ & 0.6 & $22 \cdot 2^{\mathrm{b}, \mathrm{A}}$ & $5 \cdot 1$ & $8.0^{\mathrm{a}, \mathrm{A}}$ & 0.9 & $18 \cdot 4^{\mathrm{b}, \mathrm{A}}$ & 1.3 & $20 \cdot 8^{\mathrm{b}, \mathrm{A}}$ & 2.4 \\
\hline$\sum$ PUFA & $32 \cdot 8^{\mathrm{a}, \mathrm{A}}$ & $2 \cdot 1$ & $39 \cdot 7^{\mathrm{a}, \mathrm{A}}$ & 0.3 & $38 \cdot 2^{\mathrm{a}, \mathrm{A}}$ & 6.5 & $28 \cdot 9^{a, A}$ & 1.9 & $39 \cdot 4^{\mathrm{b}, \mathrm{A}}$ & $2 \cdot 1$ & $37 \cdot 0^{\mathrm{a}, \mathrm{b}, \mathrm{A}}$ & 4.3 \\
\hline$\sum n-3$ & $19 \cdot 7^{\mathrm{a}, \mathrm{A}}$ & 1.6 & $30.6^{\mathrm{a}, \mathrm{A}}$ & 0.1 & $31 \cdot 8^{\mathrm{a}, \mathrm{A}}$ & 7.4 & $15 \cdot 4^{\mathrm{a}, \mathrm{A}}$ & 1.3 & $30 \cdot 7^{\mathrm{b}, \mathrm{A}}$ & 2.0 & $30 \cdot 3^{\mathrm{b}, \mathrm{A}}$ & $4 \cdot 1$ \\
\hline$\sum n-6$ & $12 \cdot 8^{\mathrm{a}, \mathrm{A}}$ & 0.4 & $7 \cdot 2^{\mathrm{b}, \mathrm{A}}$ & 0.1 & $5 \cdot 6^{\mathrm{b}, \mathrm{A} *}$ & $1 \cdot 1$ & $13 \cdot 0^{\mathrm{a}, \mathrm{A}_{*}}$ & 0.6 & $7 \cdot 1^{\mathrm{b}, \mathrm{A}}$ & 0.3 & $6 \cdot 8^{\mathrm{b}, \mathrm{A}_{*}}$ & 0.2 \\
\hline$\sum n-3: \sum n-6$ & $1.5^{\mathrm{a}, \mathrm{A} *}$ & 0.1 & $4 \cdot 2^{\mathrm{a}, \mathrm{A}}$ & 0.0 & $5 \cdot 9^{\mathrm{a}, \mathrm{A}}$ & $2 \cdot 4$ & $1 \cdot 2^{\mathrm{a}, \mathrm{B}}$ & 0.0 & $4 \cdot 3^{\mathrm{b}, \mathrm{A}}$ & 0.1 & $4 \cdot 5^{\mathrm{b}, \mathrm{A}}$ & 0.5 \\
\hline
\end{tabular}

MAG, monoacylglycerol; PL, phospholipids.

a,b,c For each culinary treatment, different unlike lowercase superscript letters within a row correspond to statistical differences $(P<0.05)$.

$\mathrm{A}, \mathrm{B}$ For each lipid class, different unlike uppercase superscript letters within a row correspond to statistical differences $(P<0.05)$.

* NEFA and PL values are statistically different $(P<0.05)$ from the initial NEFA and PL (raw and grilled) shown in Table 3.

in the MAG class. Conversely, stearic acid was lower in this lipid class. These results are partly explained by the differences between TAG and PL before digestion. The PL before digestion were already richer in n-3 PUFA (particularly, DHA) and poorer in MUFA (oleic acid and others) and linoleic acid. On the other hand, there were differences between the FA profiles of PL before and after digestion (Tables 3 and 5). For instance, the EPA content in the PL of raw seabream muscles was reduced from 5.6 (SD 0.1 ) to 3.7 (SD 0.7)\%. In addition, when considering the bioaccessible fractions of each lipid class, there were a few differences between the FA profiles of raw and grilled seabream. This reinforces the conclusion that, although grilling is a drastic thermal treatment, it did not cause major damage to the chemical structure of lipid molecules.

The FA profile of MAG may be due to the selectivity of lipases during digestion of TAG. This selectivity may lead to the formation of some NEFA and the relative concentration of certain FA, such as palmitic acid and DHA, in the MAG. Moreover, lipases may operate in a selective way owing to either chemical affinity or sensitivity to the position of the FA chain in the TAG. In particular, the precise nature of PPL selectivity under in vitro digestion conditions is debatable. On the one hand, although $n-3$ PUFA such as DHA are very frequently bound at the second position $(\mathrm{s} n-2)$ of TAG molecules, two other mid- or SCFA are in the lateral (1- and 3-) positions $(s n-1 / 3)^{(45)}$. This makes the rupture of the ester bond of a long-chain FA by PPL harder to achieve ${ }^{(45)}$. Conversely, FA in the $s n-1 / 3$ position are more easily hydrolysed, leading to the formation of 2-MAG by this enzyme. This hypothesis would be compatible with a large increase in DHA in the MAG (especially 2-MAG) class, as observed in the current study.

On the other hand, if, instead of regioselectivity, the FA chemical structure (namely, the number of double bonds) was decisive for PPL action ${ }^{(41)}$, this would yield DAG (and may be TAG) along with MAG (1-MAG/3-MAG besides 2-MAG) enriched in DHA and other highly unsaturated FA. The results obtained in the current study do not allow a separate analysis between 1-MAG/3-MAG and 2-MAG. However, the evidence supporting the regioselectivity hypothesis may be highlighted by the enrichment in palmitic acid of the MAG class. Palmitic acid is neither very long nor unsaturated, and thus any structural selectivity against DHA hydrolysis would not apply to palmitic acid. Although stearic acid is longer than palmitic acid, it is less concentrated in the MAG class, thus further weakening the existence of a causality link between structure and hydrolysis by the lipase. Of course, a positional selectivity of PPL presupposes that besides DHA palmitic acid is more frequently bound at the second-position ( $(s n-2)$ of TAG in fish. Precisely, it has been reported that most fish species have a higher proportion of palmitic acid in position $s n-2^{(46)}$. It is also very interesting to note that, according to this study, although myristic acid is most often concentrated in $s n-2$, stearic and oleic acids are most often found at $s n-1 / 3$. This fits perfectly with the current study's results. Therefore, in vitro lipid digestion seems to confirm a predominant regioselective action of PPL. 
The FA profiles of the lipid classes of the bioaccessible fractions attained from raw and grilled seabream may help explain the bioaccessibility differences between the FA (Table 4). However, although the high frequency of DHA in MAG and PL (PL were not as extensively hydrolysed as the TAG class) may be related to a lower DHA bioaccessibility - provided that PL and MAG have less affinity for the bioaccessible fraction - the low percentage of linoleic acid in MAG and PL did not correlate with a high bioaccessibility. Therefore, bioaccessibility differences between FA may be caused by the chemical interactions of their multiple forms (for instance, oleic acid, monoolein, glyceryl dioleate, glyceryl trioleate, etc.) to the aggregated protein in the non-bioaccessible fraction $v$. the components in the bioaccessible fraction. The higher polarity of PUFA would be decisive for a lower bioaccessibility of these FA as observed in this study.

\section{Conclusions}

In raw and grilled seabream muscles, PUFA were the most abundant FA group, followed by MUFA and SFA. The relative FA profile varied across lipid classes, being more dissimilar between TAG and PL. The latter were richer in DHA. A daily meal of grilled seabream ensures more than three times the recommended daily intake of EPA + DHA (500 mg/d).

Regarding bioaccessibility, long-chain SFA and PUFA seemed to be less bioaccessible than short-chain SFA as well as SFA and MUFA. Moreover, grilling reduced the relative portion of bioaccessible protein, fat and many FA, with the highest reductions found in PUFA such as DHA. Lipid class may have also played a role in the bioaccessibility process. However, other chemical affinity phenomena may be more influential.

Finally, it was observed that the FA composition of the MAG class correlated quite well with the position of the FA in the TAG molecule, thus providing evidence for a regioselective action of the lipase under the in vitro digestive conditions. At least for DHA, its $s n-2$ position at TAG reduced its hydrolysis degree and may have contributed for its bioaccessibility result.

\section{Acknowledgements}

This work was supported by the project 'GOODFISH', ref. no. PTDC/SAU-ESA/103825/2008, and the individual Post Doctoral Grants for the authors C. A., ref no. SFRH/BPD/64951/2009, and C. C., ref. no. SFRH/BPD/102689/2014, all of 'Fundação para a Ciência e a Tecnologia' (FCT).

S. C. carried out lipid analysis and data treatment; C. A. oversaw the bioaccessibility experimental; C. C. performed the calculations and statistical analysis and wrote the manuscript; R. O. and F. A. carried out the bioaccessibility experimental part together; M. L. N. devised the experimental design; and N. M. B. oversaw the performance of the trials and was involved in writing the manuscript.

The authors declare that there are no conflicts of interest.

\section{References}

1. Cardoso C, Afonso C, Lourenço H, et al. (2015) Bioaccessibility assessment methodologies and their consequences for the riskbenefit evaluation of food. Trends Food Sci Technol 41, 5-23.
2. Alipour HJ, Shabanpoor B, Shabani A, et al. (2010) Effects of cooking methods on physico-chemical and nutritional properties of Persian sturgeon Acipenser persicus fillet. Int Aquat Res 2, 15-23.

3. Kong F, Tang J, Rasco B, et al. (2007) Kinetics of salmon quality changes during thermal processing. J Food Eng 83, 510-520.

4. Harris PV \& Shorthose WR (1988) Meat texture. In Developments in Meat Science Vol. 4, pp. 245-296 [RA Lawrie, editor]. London: Elsevier.

5. Afonso C, Costa S, Cardoso C, et al. (2015) Evaluation of the risk/benefit associated to the consumption of raw and cooked farmed meagre based on the bioaccessibility of selenium, eicosapentaenoic acid and docosahexaenoic acid, total mercury, and methylmercury determined by an in vitro digestion model. Food Chem 170, 249-256.

6. Van Het Hof KH, West CE, Weststrate JA, et al. (2000) Dietary factors that affect the bioavailability of carotenoids. $J$ Nutr 130, 503-506.

7. Wienk KJH, Marx JJM \& Beynen AC (1999) The concept of iron bioavailability and its assessment. Eur J Nutr 38, 51-75.

8. Costa S, Afonso C, Cardoso C, et al. (2015) Fatty acids, mercury, and methylmercury bioaccessibility in salmon (Salmo salar) using an in vitro model: effect of culinary treatment. Food Chem 185, 268-276.

9. Dyerberg J, Madsen P, Møller JM, et al. (2010) Bioavailability of marine $n-3$ fatty acid formulations. Prostaglandins Leukot Essent Fatty Acids 83, 137-141.

10. Neubronner J, Schuchardt JP, Kressel G, et al. (2011) Enhanced increase of omega-3 index in response to long-term $n-3$ fatty acid supplementation from triacylglycerides versus ethyl esters. Eur J Clin Nutr 65, 247-254.

11. Simopoulos AP (2002) Omega-3 fatty acids and cardiovascular disease: the epidemiological evidence. Environ Health Prev Med 6, 203-209.

12. Food and Agriculture Organization (2014) The State of World Fisheries and Aquaculture. Opportunities and Challenges. Rome: FAO of the UN.

13. Costa S, Afonso C, Bandarra NM, et al. (2013) The emerging farmed fish species meagre (Argyrosomus regius): how culinary treatment affects nutrients and contaminants concentration and associated benefit-risk balance. Food Chem Toxicol 60, 277-285.

14. Trevisan AJB, Lima DA, Sampaio GR, et al. (2016) Influence of home cooking conditions on Maillard reaction products in beef. Food Chem 196, 161-169.

15. Association of Analytical Communities (2000) Official Methods of Analysis of the Association of Official Analytical Communities International, 17 th ed. Gaithersburg, MA: Association of Analytical Communities.

16. Saint-Denis T \& Goupy J (2004) Optimization of a nitrogen analyser based on the Dumas method. Anal Chim Acta $\mathbf{5 1 5}$, 191-198.

17. Smedes F (1999) Determination of total lipid using nonchlorinated solvents. Analyst 124, 1711-1718.

18. Bandarra NM, Batista I, Nunes ML, et al. (2001) Seasonal variation in the chemical composition of horse-mackerel (Trachurus trachurus). Eur Food Res Technol 212, 535-539.

19. Bandarra NM, Batista I, Nunes ML, et al. (1997) Seasonal changes in lipid composition of sardine Sardina pilchardus. J Food Sci 62, 40-43.

20. Weihrauch JL, Posati LP, Anderson BA, et al. (1977) Lipid conversion factors for calculating fatty acids contents in foods. J Am Oil Chem Soc 54, 36-40.

21. Zar JH (1999) Biostatistical Analysis, 4th ed. Upper Saddle River, NJ: Prentice-Hall Inc. 
22. Stubhaug I, Tocher DR, Bell JG, et al. (2005) Fatty acid metabolism in Atlantic salmon (Salmo salar L.) hepatocytes and influence of dietary vegetable oil. Biochim Biophys Acta 1734, 277-288.

23. Valente LMP, Cornet J, Donnay-Moreno C, et al. (2011) Quality differences of gilthead sea bream from distinct production systems in Southern Europe: intensive, integrated, semi-intensive or extensive systems. Food Control 22, 708-717.

24. Benedito-Palos L, Ballester-Lozano GF, Simó P, et al. (2016) Lasting effects of butyrate and low FM/FO diets on growth performance, blood haematology/biochemistry and molecular growth-related markers in gilthead sea bream (Sparus aurata). Aquaculture 454, 8-18.

25. Nasopoulou C, Karantonis HC \& Zabetakis I (2011) Nutritional value of gilthead sea bream and sea bass. Dynam Biochem Proc Biotech Mol Biol 5, 32-40.

26. Aursand M, Bleivik B, Rainuzzo JR, et al. (1994) Lipid distribution and composition of commercially farmed Atlantic salmon (Salmo salar). J Sci Food Agric 64, 239-248.

27. Wassef EA, Saleh NE \& El-Hady HAE (2009) Vegetable oil blend as alternative lipid resources in diets for gilthead seabream, Sparus aurata. Aquacult Int 17, 421-435.

28. Weber J, Bochi VC, Ribeiro CP, et al. (2008) Effect of different cooking methods on the oxidation, proximate and fatty acid composition of silver catfish (Rhamdia quelen) fillets. Food Chem 106, 140-146.

29. Little SO, Armstrong SG \& Bergan JG (2000) Factors affecting stability and nutritive value of fatty acids: culinary practices. In Fatty Acids in Foods and their Health Implications, pp. 427-437 [CK Chow, editor]. New York, NY: CRC Press.

30. Kris-Etherton P, Harris W, Appel L, et al. (2002) Fish consumption, fish oil, omega-3 fatty acids, and cardiovascular disease. Circulation 106, 2747-2757.

31. Alasalvar C, Taylor KDA, Zubcov E, et al. (2002) Differentiation of cultured and wild sea bass (Dicentrarchus labrax): total lipid content, fatty acid and trace mineral composition. Food Chem 79, 145-150.

32. Yildiz M, Sener E \& Timur M (2006) The effects of seasons and different feeds on fatty acid composition in fillets of cultured gilthead sea bream (Sparus aurata L.) and European sea bass (Dicentrarchus labrax L.) in Turkey. Turk J Vet Anim Sci 30 , 133-141.

33. Ibeas C, Cejas JR, Fores R, et al. (1997) Influence of eicosapentaenoic to docosahexaenoic acid ratio (EPA/DHA) of dietary lipids on growth and fatty acid composition of gilthead seabream (Sparus aurata) juveniles. Aquaculture 150, 91-102.

34. Menoyo D, Lopez-Bote CJ, Bautista JM, et al. (2003) Growth, digestibility and fatty acid utilization in large Atlantic salmon (Salmo salar) fed varying levels of $n-3$ and saturated fatty acids. Aquaculture 225, 295-307.

35. Ruiz-Lopez N, Stubhaug I, Ipharraguerre I, et al. (2015) Positional distribution of fatty acids in triacylglycerols and phospholipids from fillets of Atlantic salmon (Salmo salar) fed vegetable and fish oil blends. Mar Drugs 13, 4255-4269.

36. Sargent JR, Tocher DR \& Bell JG (2002) The lipids. In Fish Nutrition, 3rd ed. pp. 181-257 [JE Halver and RW Hardy, editors]. San Diego, CA: Academic Press.

37. Izquierdo M (2005) Essential fatty acid requirements in Mediterranean fish species. Cahiers Options Méditerranéennes $\mathbf{6 3}$, 91-102.

38. Bandarra NM, Rema P, Batista I, et al. (2011) Effects of dietary $n-3 / n-6$ ratio on lipid metabolism of gilthead seabream (Sparus aurata). Eur J Lipid Sci Biotechnol 113, 1332-1341.

39. Dadorama S (1996) Amino acids, peptides, and proteins. In Food Chemistry, 3rd ed. pp. 321-429 [OR Fennema, editor]. New York, NY: Marcel Dekker Inc.

40. Lien EL (1994) The role of fatty acid composition and positions distribution in fat absorption in infants. I Pediatrics $\mathbf{1 2 5}$, S62-S68.

41. Akanbi TO, Sinclair AJ \& Barrow CJ (2014) Pancreatic lipase selectively hydrolyses DPA over EPA and DHA due to location of double bonds in the fatty acid rather than regioselectivity. Food Chem 160, 61-66.

42. Gervais R, Gagnon F, Kheadr EE, et al. (2009) Bioaccessibility of fatty acids from conjugated linoleic acid-enriched milk and milk emulsions studied in a dynamic in vitro gastrointestinal model. Int Dairy J 19, 574-581.

43. Martin D, Nieto-Fuentes JA, Señoráns FJ, et al. (2010) Intestinal digestion of fish oil and $\omega 3$-concentrates under in vitro conditions. Eur J Lipid Sci Technol 112, 1315-1322.

44. Michalski MC, Genot C, Gayet C, et al. (2013) Multiscale structures of lipids in foods as parameters affecting fatty acid bioavailability and lipid metabolism. Prog Lipid Res 52, 354-373.

45. Schuchardt JP \& Hahn A (2013) Bioavailability of long-chain omega-3 fatty acids. Prostaglandins Leukot Essent Fatty Acids 89, $1-8$.

46. Brockerhoff H, Hoyle RJ, Hwang PC, et al. (1968) Positional distribution of fatty acids in depot triglycerides of aquatic animals. Lipids 3, 24-29. 